\title{
HYGIENE FROM THE HEART: THE RISE OF SHARIA COMPLIANT HOTEL IN INDONESIA AFTER COVID-19 PANDEMIC
}

\author{
Noveri Maulanaa, \\ Restia Oktaviaman', \\ Yasmine Farah ${ }^{c}$ \\ aDepartment of Management, PPM School of Management, \\ Sekolah Tinggi Manajemen PPM \\ b,c Magister Management Program, PPM School of Management, \\ Sekolah Tinggi Manajemen PPM \\ Email: nvr@ppm-manajemen.ac.id a; restiaoktaviaman@gmail.com ${ }^{\text {b }}$; yasminefarah.2007@gmail.com ${ }^{c}$
}

\section{ARTICLE HISTORY}

Received:

9 September 2020

Revised:

12 November 2020

Accepted:

29 November 2020

Online available:

11 December 2020

Keywords:

Halal Hotel,

Marketing Strategy,

Pandemic COVID-19,

Sharia-compliant hotel,

Tourism

*Correspondence:

Name: Noveri Maulana

E-mail:

nvr@ppm-

manajemen.ac.id

\section{ABSTRACT}

The development of Sharia-compliant hotel (SCH) in Indonesia is rapidly growing since 2012. However, the COVID-19 pandemic has changed the business development of $\mathrm{SCH}$ and in the Halal Tourism Industry. This paper aims to develop an alternative strategy for $\mathrm{SCH}$ to rebuild the market after the pandemic situation. This research is specified the marketing strategy to attract domestic tourist, especially Muslim tourist to prefer Sharia-compliant hotel in their travelling destinations. As the primary object of the research, this paper is using a well-known sharia hotel in Jakarta as the single case study analysis. Mix method approach is implemented in this study, which used quantitative and qualitative data. All the data are formulated in Threat, Opportunity, Weakness, Strength (TOWS) Matrix. The result of strategy formulation in the matrix will produce several alternatives of marketing strategy, which might be implemented by the SCH management in Indonesia. Survey was conducted before the COVID-19 pandemic to 197 respondents to evaluate the service quality and the decision-making process of the consumer towards SCH in Jakarta. In-depth interview and focus group discussion (FGD) were conducted with the board of directors to follow up the survey and to implement internal validity with the hotel management. Documents review and observation were also implemented. Based on strategy formulation in TOWS Matrix, this research is proposed three strategic marketing programs which could be implemented by Sharia Compliance Hotel toward the new adaptation era after the pandemic. Those strategies are discussed in the result analysis.

\section{INTRODUCTION}

The COVID-19 Pandemic has been affecting the tourism industry since its outbreak in early 2020. The crisis in the industry has caused economic impact to the business process and its sustainability. Major problems are raising, such as decreasing in revenue, employee layoff, increase in debt, and other several problems faced by 
business practitioners in the tourism sectors. This major problem in tourism industry has been reported in many countries in the world during COVID-19 pandemic (Gössling et al., 2020) and predicted to continue until the government implements official vaccination programs.

The COVID-19 pandemic impact on the tourism industry has been visible since the government announced travel ban in most countries affecting $90 \%$ of the tourism destinations and leisure businesses (Gössling et al., 2020). Indonesian tourism as one of the popular tourist destinations in the world is also impacted by this pandemic situation. Moreover, this continuing crisis could lead to a bigger impact on the tourism industry, especially small medium enterprises (SME) in tourist destinations which are highly dependent on tourists as their primary consumers.

According to the report and press release by Indonesia Halal Tourism Association or Perkumpulan Pariwisata Halal Indonesia (PPHI) during the virtual Indonesia Sharia Economy Festival (ISEF) on 27-29 October 2020, the tourism industry in Indonesia, especially halal tourism, is in defensive strategy to maintain its sustainability. During this virtual seminar, the chairman of PPHI stated that $90 \%$ of halal tourism businesses such as hotels, tour and travel agencies, and restaurants were influenced by the pandemic and even some businesses should be shut down for months.

While tour and travel agencies can pivot their business to other services such as becoming retail agencies and consultants, the hotel business is still in defensive mode and being threatened to get in more difficult situation while travel ban is still applied. Hotel industry does not have the possibility to pivot their business since its non-liquid asset should be always maintained during crisis. The Sharia-compliant hotel $(\mathrm{SCH})$ is one among affected businesses during this COVID-19 pandemic and will encounter more challenges after the pandemic for their future market development. As a niche market, $\mathrm{SCH}$ is still in an infant stage in tourism and Indonesian market (Winarti, 2017). The specificity in their services leads them to improve their marketing campaign to the Muslim segment as a travel accommodation (Jeaheng et al., 2019). But, in this pandemic situation, $\mathrm{SCH}$ and Halal Tourism, in broader context, should have bigger concern on their future strategy to rebuild the industry and develop their market after the pandemic with their new adaptation strategies.

Before the COVID-19 pandemic, the development of Sharia-compliant hotel in Indonesia has been increasing rapidly. Based on data release by $\mathrm{PPHI}$, halal tourism in Indonesia has been significantly rising each year since 2012. In 2015 and 2016, Indonesian Halal Tourism was acknowledged by the international tourism bureau by awarding some tourist destinations in the country as halal tourism destinations (Lombok and West Sumatera), and some hotels and tour agencies were also granted as halal tourism service providers (Sofyan Hotel Jakarta and Lombok Tours). Furthermore, based on data from Global Muslim Travel Index (GMTI) by Crescent Rating based in Singapore, the economic potential of Muslim travelers around the 
world is currently increasing and expected to reach $35 \%$ growth by 2026 . One leading halal tourism destination is in Indonesia, providing ten halal destinations across the nation. This data mean a significant growth of $\mathrm{SCH}$ in Indonesia and allows a big opportunity for halal tourism businesses, including SCH business.

However, this projection was planned before the COVID-19 pandemic. In this difficult situation, halal tourism, Sharia-compliant hotel in particular, needs a new strategy development to execute for the new market adaptation. This paper aims to answer those challenges, offering an alternative for $\mathrm{SCH}$ management to develop their marketing strategy to rebuild the business after COVID-19 pandemic. strategy in developing the tourism market is important to every business practitioner (Fauzi et al., 2020; Mohammad et al., 2019).

This research intends to describe the $\mathrm{SCH}$ market development strategy in Indonesia, mainly after COVID-19 pandemic. As the Ministry of Tourism and Creative Economy suggests, the primary target market in the new adaptation era in tourism industry should be the local tourists, while the government is still enacting the limitation for foreign tourists to come to Indonesia. Therefore, this research specifies the marketing strategy to attract domestic tourists, notably Muslim tourist to choose Sharia-compliant hotel for their travelling destinations. As the research primary object, this essay uses a well-known sharia hotel in Jakarta in the single case study analysis. This paper applies Mix method approach with quantitative and qualitative data. All the data are formulated in Threat, Opportunity, Weakness, Strength (TOWS) Matrix. The results of strategy formulation matrix will produce several alternatives of marketing strategies for SCH management may implement.

\section{LITERATURE REVIEW}

Before the COVID-19 pandemic, the increasing number of $\mathrm{SCH}$ was in a tough situation since its demand was limited among the Muslim markets. Some shariacompliant hotels argued that the competition in the halal industry was challenging, as well as lack of awareness of Muslim market in the competition between SCH and conventional hotels (Henderson, 2009; Mohsin et al., 2016; Usman et al., 2019). Although government supports the $\mathrm{SCH}$ development, winning the competitive market remains tricky for the sharia-compliant hotel businesses.

Conversely, the semantic debate among halal tourism stakeholders regarding to halal standards and its competitive value among the businesses, is affecting the industry development. Sharia-compliant hotel is considered in an infant stage for its development and requires further research towards a comprehensive model, mainly the halal certification standards for its services (Winarti, 2017). The SCH business model remains debatable and has various perspectives on some practical implementations. The concept implementation of $\mathrm{SCH}$ in the Middle East may differ with one in the South-East Asia and the Muslim community in the Western region (Jafari \& Scott, 2014). This phenomenon encourages researchers to analyze and 
understand the $\mathrm{SCH}$ concept and its implementation in various regions, including Indonesia.

Battour and Ismail (2016) suggest at least four aspects of Halal Tourism can be standardized for Muslim tourist. The determinants of this Halal tourism are Islamic facilities such as praying rooms and adequate toilets, Halal Food and beverages, Islamic cultures and services, and alcohol-free beverages (Battour \& Ismail, 2016). Those standards are brought in Sharia-compliant hotel to meet Muslim consumers' requirement. The evaluation of the halal tourism determinants will enhance the halal travel experience for Muslim tourists (Abror et al., 2019; Al-Ansi \& Han, 2019; Rodrigo \& Turnbull, 2019; Saputro et al., 2018).

Currently, competition in Indonesian hotel industry is getting higher, this has been occurring since the increasing number of new hotel improvements in major cities in the country. Suwanto (2020) explains a soaring trend of occupancy rate in Jakarta during 2012-2018, when the total number of foreign tourists is also increasing. there is a significant correlation between the number of tourists and hotel rooms in Jakarta (Suwanto, 2020). As predicted by the Ministry of Tourism, there will be a significance growth of foreign tourists visiting Indonesia, mainly in Jakarta. Therefore, one development rapidly expanding in Jakarta is the number of new high qualified hotels coming every year. However, those predictions are made before COVID-19 pandemic. the growth number of hotels will be potentially over supply within the industry in the recent situation.

Sharia-compliant hotel is a hotel whose operations and services must follow the basic principles of Islamic law (sharia) approved by the Indonesian Ulama Council (Bahasa: MUI). In this case, hotels following sharia principles do not serve alcohol and have separate swimming pools and spa facilities for men and women (Jaelani, 2017). Furthermore, there are seven standards of $\mathrm{SCH}$ as stated by the MUI that $\mathrm{SCH}$ should not provide any medium or channels to porn and its related activities, provide any entertainment facility which may lead to unethical activities against the rule of Islam (sharia), all food and beverages must be served under halal certification by the official council (Ratnasari et al., 2020), provide supporting facilities for Muslim to pray, employee and staff must be dressed in Islamic proper way, management should create guidance and operating procedure available informing their Halal standards, and $\mathrm{SCH}$ should apply financial services from halal banks and sharia financing organizations (USMAN et al., 2020).

Despite of Sharia principles implementation, in terms of formulating a marketing strategy, the analytical tools employed can rely on conventional business strategies concept (Jia \& Chaozhi, 2020). But the basis for strategic consideration must refer to Islamic values as the key to successful Sharia principles implementation. For example, in preparing a marketing strategy, Segmenting, Targeting, and Positioning (STP) concept and Marketing Mix also refer to the concept of marketing management 
in general (Kotler, 2011). In addition, in developing alternative strategies, TOWS Matrix can be an alternative in developing a marketing strategy.

TOWS Matrix is a tool to create a company strategy, how opportunities and threats are adjusted according to strengths and weaknesses. There are four strategies in TOWS Matrix. First, SO (strengths-opportunities) strategies designed using company's strengths to gain opportunities from external environment. Second, WO (weakness-threats) strategies aiming to improve internal weaknesses by taking opportunities in the environment. third is ST (strengths-threats) strategies formulated by using company strengths to overcome or reduce the impact of environmental threats. fourth is WT (weakness-threats) strategies as defensive tactics to reduce internal weakness and the impact of threats (David et al., 2017; Fred, 2015; Ravanavar, 2012). Meanwhile, in compiling a marketing strategy for service products, the marketing mix applies 'Seven P's (Lovelock \& Gummesson, 2004). The service marketing mix consists of seven elements which are product, price, place, promotion, process, physical environment, and people.

First, Product, is an element not only a core service product providing main benefits offered by consumers but also a supplementary service to support services and increase service value as an advantage. Supplementary service consists of information, order taking, billing, payment, consultation, hospitality, safekeeping, and exceptions (Kotler, 2011).

The second is Price. after the product or service is decided, the price is determined as the basis for offering to consumers. Pricing can be carried out with a price-setting approach, namely cost-based pricing, value-based pricing, and competition-based pricing. Where pricing can be adjusted based on cost, value and competition. Third, Place, is a place or medium for products distribution. Distribution involves physical, electronic channels, or both. The ease and speed of place and time are essential for effective distribution (Bradford \& Boyd, 2020).

The fourth is Promotion, a form of communication and education that directs consumers during the service process. Promotions can be done in various ways including sales promotion, personal selling, direct marketing, and advertising. Fifth, Process, is design and management of customer service processes for demand and supply management, to ensure consistency in service quality provided to consumers (Abodeeb et al., 2015). The sixth is physical environment, service-scape or service delivery process facilities, and visible evidence of service quality and company image to consumers. The seventh is People, regarding with recruitment, training, employee motivation to provide quality and productive services (Lovelock \& Gummesson, 2004). Since the quality of service affects the services given by service providers (Al-Ansi \& Han, 2019). 


\section{RESEARCH METHOD}

This study adopts mix method approach in its analysis. The mix method analysis is conducted in two steps, first is by preparing analyzed quantitative data through survey to produce descriptive analysis. Descriptive data will be interpreted into several TOWS matrix categories to formulate the alternative strategies for future development. Second approach in data analysis lies on qualitative method through interview, FGD, and document review from several sources.

Unlike quantitative research, qualitative research describes the result in a narrative conclusion encouraging the audience to a deeper understanding of the research objectives. Therefore, qualitative data is popularly used in social science research projects, including business and management studies (Maulana, 2017).

While quantitative research explains the study results in statistical reports, qualitative data provide the results in narrative sentences. Hence, qualitative data answer the research question "Why" and "How", purposely differ with quantitative data which commonly answer "What" and "When" research questions. Furthermore, Maxwell (2002) explains that qualitative data have richness and comprehensiveness in revealing complexity which the data will explain the study objects. It seems the result of qualitative data is more sensing the 'real life' and explains of the meaning of the actual phenomenon in the study (A. Huberman \& Miles, 2012; Maulana, 2020b).

This research applies a single case study approach sharia-compliant hotel that focuses on the analysis and implementation of sharia-compliant hotel business strategy in Indonesia. Data collection was carried out through in-depth interview, focus group discussion, observations, documents review, and consumer survey using questionnaires (Sekaran \& Bougie, 2011). However, the survey which was conducted of 197 respondents only described the mean and modus of the data. This descriptive analysis is used to categorize the data into TOWS Matrix which summarizes the strength, weaknesses, opportunity, and Threat of the hotel businesses (Maulana, 2020a; Weihrich, 1982).

The Data collection processes were conducted in two separate periods. The First data collection was carried out before COVID-19 pandemic in Indonesia (20182019), and the second data collection was carried out during COVID-19 pandemic (August - October 2020). This data collection for the first period was conducted through surveys, FGDs, and In-depth interviews. The Survey collected 197 data from respondents who had stayed at 3 Star Hotels in Jakarta during 2018-2019 (before COVID-19 pandemic). Purposive sampling method and descriptive data analysis were conducted through Microsoft Excel to summarize the values of mean, median, and modus. Furthermore, this descriptive data is used as raw data for strategy formulation in TOWS Matrix. On the other hand, first round of FGD and In-depth interview were also conducted in 2019 to capture the situation before the pandemic. All data were written and interpreted in these data collections using a content and context analysis approach. Content analysis is a method for subjective interpretation of text data 
content through a systematic classification process of coding and identifying themes or patterns (Maulana, 2020b).

The Second data collection was performed during the COVID-19 pandemic in Indonesia, mainly during August-October 2020 through in-depth interview, FGD, and document review. This second rounds of in-depth interview invited the $\mathrm{SCH}$ directors as the research object of this single case study. FGDs were conducted virtually with the Halal Tourism Association (Bahasa: PPHI) through "PPHI Friday Night Talk" event during September-October 2020. In total, there are 4 FGD's for data collection from halal tourism practitioners, particularly the directors and owners of $\mathrm{SCH}$. Meanwhile, document reviews were carried out to compare macro and micro-economic data on the Tourism industry in the periods before and after the COVID-19 pandemic. Documents are collected from official sources such as reports from the Ministry of Tourism, the Ministry of Economy, Bank of Indonesia, Central Bureau of Statistics, and from several tourism Associations.

All data collected are categorized using the same codes which is related to the pattern that researcher has proposed based on the concept and the theory as the research basis. Content Validity is also required in qualitative research (Ptok et al., 2018). Content validity refers to operationalization checking against the relevant content domain for the construct. In this research, content validity was implemented through FGD, interview, and observation to ensure that all research variables and operationalization will develop correctly and be understood perfectly by respondents (Snyder, 2019). Once the patterns are found, a strategic analysis can be carried out through TOWS Matrix. This strategic tool is the final step of the analysis that produces alternative strategies for the sharia-compliant hotel in developing their marketing strategy. 
Table 1

Research Data Types and Sources

\begin{tabular}{|c|c|c|c|}
\hline No & Description of Data & Data Sources & $\begin{array}{l}\text { Data Collection } \\
\text { Method }\end{array}$ \\
\hline 1 & $\begin{array}{l}\text { Tourists Statistic and Hotel } \\
\text { Occupancy in Jakarta }\end{array}$ & $\begin{array}{l}\text { The Ministry of Tourism and Creative } \\
\text { Economy \& Central Bureau of Statistics } \\
\text { (Bahasa: BPS) }\end{array}$ & Documents Review \\
\hline 2 & $\begin{array}{l}\text { Tourists' Behavior in Jakarta (length } \\
\text { of stay \& others) }\end{array}$ & $\begin{array}{l}\text { The Ministry of Tourism and Creative } \\
\text { Economy }\end{array}$ & Documents Review \\
\hline 3 & Competitors Analysis & $\begin{array}{l}\text { Board of Directors, Public Expose of } \\
\text { Hotel Associations, and Central Bureau } \\
\text { of Statistics (Bahasa: BPS) }\end{array}$ & $\begin{array}{l}\text { FGD \& Documents } \\
\text { Review }\end{array}$ \\
\hline 4 & $\begin{array}{l}\text { Consumer Decision Making Process } \\
\text { on Hotel Selection }\end{array}$ & $\begin{array}{l}\text { Survey of } 197 \text { respondents at } 3 \text { stars } \\
\text { hotels in central Jakarta. }\end{array}$ & $\begin{array}{l}\text { Survey } \\
\text { (questionnaire) }\end{array}$ \\
\hline 5 & $\begin{array}{l}\text { Marketing Budget \& Return on } \\
\text { Marketing Investment }\end{array}$ & Financial Report of the Hotel. & Document Review \\
\hline 6 & $\begin{array}{l}\text { Segmenting, Targeting, } \\
\text { Positioning Analysis }\end{array}$ & Directors & In-Depth Interview \\
\hline 7 & Marketing Mix Analysis & $\begin{array}{l}\text { Directors, Tourism Association, and } \\
\text { Consumer's Survey }\end{array}$ & $\begin{array}{l}\text { FGD and In-depth } \\
\text { interview }\end{array}$ \\
\hline 8 & $\begin{array}{l}\text { Halal Tourism and Sharia-compliant } \\
\text { hotel Literatures }\end{array}$ & $\begin{array}{l}\text { Publications, Mass Media, and } \\
\text { Academic Journals }\end{array}$ & $\begin{array}{l}\text { Document and } \\
\text { Literature Review }\end{array}$ \\
\hline
\end{tabular}

Source: Based on author's analysis

\section{RESULTS AND ANALYSIS}

After collecting data, the researcher then classifies the data according to predetermined codes and categories. The code used is in accordance with the TOWS SWOT-components, namely Strength (S), Weakness (W), Opportunity (O), and Threat (T). Each code component will be assigned a number, indicating data order in each of these categorizations. Data on Strength (S) and Weakness (W) are summarized from company internal survey of service excellences, interview with board of directors, and based on hotels financial and annual report. Meanwhile, data on Opportunity (O) and Threat $(\mathrm{T})$ are summarized from external analysis such as document review on BPS report, public data on the Ministry of Tourism website, and survey of Consumer Decision Making process (CDMP) of hotel visitors in Jakarta. From the results of external analysis through market analysis, industry analysis, and consumer analysis, there are several opportunities $(\mathrm{O})$ and threats $(\mathrm{T})$ in the hotel industry in Indonesia. Due to page limitations, a summary of the outcome data analysis is presented in Table 2. 
Table 2

Data Summary of External Analysis

\begin{tabular}{|c|c|c|c|}
\hline No & Data Summary & Category & Code \\
\hline 1 & $\begin{array}{l}\text { Demand for hotels has decreased in the pandemic era and is } \\
\text { predicted to continue until COVID- } 19 \text { vaccine is distributed. }\end{array}$ & Threat & T1 \\
\hline 2 & $\begin{array}{l}\text { Limited qualified marketeers and sales forces from hotel } \\
\text { management due to layoff decision by directors/owner during the } \\
\text { pandemic situation. }\end{array}$ & Threat & T2 \\
\hline 3 & $\begin{array}{l}\text { Ease of access to information (especially through online travel } \\
\text { agents and other online applications) makes it easier for consumers } \\
\text { to compare hotels with one another }\end{array}$ & Threat & T3 \\
\hline 4 & $\begin{array}{l}\text { The large number of hotels and rooms in DKI Jakarta, including non- } \\
\text { formal accommodation such as AirBnB, Apartment rental, and } \\
\text { others. }\end{array}$ & Threat & T4 \\
\hline 5 & $\begin{array}{l}\text { Sharia-compliant hotel or Halal Hotel is still not a priority choice for } \\
\text { most users, even for Muslim segmentation }\end{array}$ & Threat & T5 \\
\hline 6 & $\begin{array}{l}\text { The implementation of Health and Safety protocol is urgently } \\
\text { required by every hotel and is fully supported by the government } \\
\text { through CHSE certification program. }\end{array}$ & Opportunity & 01 \\
\hline 7 & $\begin{array}{l}\text { There is a great possibility to use online travel agencies and } \\
\text { promotional website to promote sharia-compliant hotels }\end{array}$ & Opportunity & 02 \\
\hline 8 & Number of suppliers with small switching costs available & Opportunity & 03 \\
\hline 9 & $\begin{array}{l}\text { The development of tourism objects and halal tourism in DKI } \\
\text { Jakarta }\end{array}$ & Opportunity & 04 \\
\hline 10 & $\begin{array}{l}\text { There is a prediction that after the pandemic, there will be an } \\
\text { increase in the number of tourists, hotel guests in DKI Jakarta, and } \\
\text { companies in Indonesia (based on the Ministry of education, GMTI, } \\
\text { and PPHI). }\end{array}$ & Opportunity & 05 \\
\hline 11 & $\begin{array}{l}\text { Online (search engines, social media, and online travel agents) is the } \\
\text { source of information reservation places for the majority of } \\
\text { consumers }\end{array}$ & Opportunity & 06 \\
\hline 12 & $\begin{array}{l}\text { Hotel specifications (price, location, convenience, and facilities) and } \\
\text { hotel reviews are a consumer's consideration in choosing a hotel. }\end{array}$ & Opportunity & 07 \\
\hline
\end{tabular}

Source: Author's Analysis

The impact of COVID-19 on the hotel industry leads to several employee layoff decision in several sharia-compliant hotels in Jakarta. Therefore, the need for quality workforces can be a threat to rebuild the post-pandemic era strategy (T2). Furthermore, if the manager employs as many employees as a normal business process, cashflow problem will occur and more difficult situation can become a hazard trap for management. Therefore, the need for hotel demand can be a mutually beneficial solution to overcome this problem (T1). This conclusion is summarized based on in-depth interview with board of directors and based on secondary data analysis from document and literature review. This conclusion is similar to research on the impact of COVID-19 on several businesses in the world such as the individual health industry (de Caro et al., 2020), online businesses (Hasanat et al., 2020), and also the impact of COVID-19 on the global economy (Fernandes, 2020).

Based on the microeconomic analysis of the industrial landscape by the Tourism Association, one of the hotel replacement products currently popular in Indonesia is AirBnb (air bed and breakfast), a special marketplace to offer lodging. 
Airbnb is an application that allows someone to rent out his unused rooms, houses, apartments, and other accommodations for travelers at very affordable prices (T3). The presence of Airbnb is quite a threat to the hotel business, because it has started to erode the occupancy of hotels, especially the middle and lower segment (T4). Although this threat needs to be addressed immediately, this Airbnb still has shortcomings and there are still many consumers who prefer hotels because of the certainty of security compared to Airbnb (O3). competition in the accommodation industry will make customers have higher bargaining power to compare prices between alternatives and also the low cost of switching between accommodations (O3). However, in the sharia-compliant hotel industry, the possibility of new hotel chains or brands entering is still high, due to prediction on the development of halal tourism in the coming years (Fajriyati et al., 2020; Han et al., 2019; Mohsin et al., 2016).

The hotel industry's target market consists of several segments, such as tourists, which can be categorized as personal or leisure consumers. another segment is the B2B market where companies and governments usually use hotels for their business meetings $(\mathrm{O} 2, \mathrm{O} 3)$. Although only a few companies in Indonesia are hotel consumers in Jakarta, this figure illustrates the company's large market potential (O4). Based on our data analysis, after the pandemic, the need for corporate activity such as hotel meeting and gathering will be slowly increasing (05). Apart from the corporate segment, the tourist segment also has great potential. Every year the tourists who come to Jakarta always increase. And it is expected to increase after the pandemic (O5). It could be a great opportunity for hotels as management implements the CHSE and other COVID-19 health protocols (01).

Based on the survey, out of 197 total respondents, $64.5 \%$ of respondents search for information when using hotel services through online travel agents, and $16.2 \%$ search through websites or the internet. Only $12.2 \%$ of respondents who seek information through social media. This shows that consumers search more for hotel information through online information compared to other information sources (06). As many as $37.1 \%$ of respondents state that the main reason respondents choose to use the hotel is because of the facilities offered by the hotel. The second reason that becomes the majority of respondents' answers, namely $41.1 \%$, is the comfort of the hotel room (O2). Other reasons that are answered most by respondents are due to the certainty of security, ease of reservation, and services provided (01). Most of the respondents (69.5\%) use hotel accommodation for their vacation needs. It is found that 171 respondents $(86.8 \%)$ make hotel reservations through online reservations, $7.6 \%$ make direct telephone reservations to the selected hotel, and the remaining $5.6 \%$ make direct reservations to hotels. These results illustrate that today's consumers prefer online hotel bookers. If respondents book hotels online, $90.4 \%$ of respondents choose to book through Online Travel Agent (OTA) and 9.6\% others through the official website of the selected hotel. 
Similar to external analysis, internal analysis is concluded into two categories, namely Strength (S) and Weakness (W). Both categories have been identified through data analysis, and the result of content and context analysis have been coded. A detailed summary of the result analysis is shown in Table 3 below.

Table 3

Data Summary of Internal Analysis

\begin{tabular}{|c|c|c|c|}
\hline No & Data Summary & Category & Code \\
\hline 1 & $\begin{array}{l}\text { The sales team always provides consulting and service } \\
\text { recommendations to consumers }\end{array}$ & Strength & S1 \\
\hline 2 & $\begin{array}{l}\text { SCH Hotel employees have high hospitality and courtesy in providing } \\
\text { services to guests }\end{array}$ & Strength & S2 \\
\hline 3 & Hotel location is strategic in the city center & Strength & S3 \\
\hline 4 & $\begin{array}{l}\text { Room prices offered are considered competitive with other } \\
\text { competitors. }\end{array}$ & Strength & S4 \\
\hline 5 & $\begin{array}{l}\text { Islamic nuances are felt in the hotel with the call to prayer and the } \\
\text { polite and Islamic appearance of hotel employees }\end{array}$ & Strength & S5 \\
\hline 6 & $\begin{array}{l}\text { The Hotel building is one of the cultural heritages established by the } \\
\text { government. }\end{array}$ & Strength & S6 \\
\hline 7 & $\begin{array}{l}\text { There are weaknesses in controlling the implementation of hygiene } \\
\text { service standards }\end{array}$ & Weakness & W1 \\
\hline 8 & $\begin{array}{l}\text { Variety of food menus in the restaurant is minimal because halal } \\
\text { certification is limited to the menu available }\end{array}$ & Weakness & W2 \\
\hline 9 & $\begin{array}{l}\text { Lack of provision of information on Sharia services that characterizes } \\
\text { potential customers }\end{array}$ & Weakness & W3 \\
\hline 10 & $\begin{array}{l}\text { There are differences in skills between employees in serving guests so } \\
\text { that it has an impact on service quality. }\end{array}$ & Weakness & W4 \\
\hline 11 & The quality of digital marketing content is still not optimal & Weakness & W5 \\
\hline 12 & $\begin{array}{l}\text { Marketing activities are still less diverse and there are still many hotel } \\
\text { marketing activities that can be developed }\end{array}$ & Weakness & W6 \\
\hline 13 & $\begin{array}{l}\text { There is a communication error regarding responsibilities and job } \\
\text { descriptions in several divisions }\end{array}$ & Weakness & W7 \\
\hline 14 & $\begin{array}{l}\text { Lack of physical characteristics as a classy Islamic hotel in customers' } \\
\text { perspectives }\end{array}$ & Weakness & w8 \\
\hline
\end{tabular}

Source: Author's Analysis

The data summary in Table 3 is the result of FGD, in-depth interview, and document review carried out before and after pandemic situation. This conclusion suggests that our analysis is related to hotel development in this pandemic situation. thus, to formulate a future development strategy, it is necessary to collect data from previous condition and compare them with hotel's current situation. Therefore, this formulation can be beneficial for SCH for future development after the COVID-19 pandemic.

After summarizing the data analysis, all data will then be formulated in the TOWS Matrix according to their respected categories. The TOWS Matrix will match external factors (Opportunity and Threat) with Internal factors (Strength and Weakness) to formulate the strategies. Then, four strategic categories will be generated, namely SO Strategy (Strength-Opportunity), ST Strategy (Strength-Threat), WO Strategy (Weakness-Opportunity), and WT Strategy (Weakness-Threat). The results of the TOWS Matrix analysis are shown in Table 4. 
Table 4

Result of TOWS Matrix Analysis

\begin{tabular}{|c|c|c|c|}
\hline No & Strategy Formulation & Components & Code \\
\hline 1 & $\begin{array}{l}\text { Communicating new values that have been formed as an identity } \\
\text { for hotel hospitality, especially in the context of Occupational } \\
\text { Health and Safety standard in avoiding the COVID-19 pandemic. }\end{array}$ & $\begin{array}{l}\text { S1; S2; O2; } \\
\quad \text { O6 }\end{array}$ & SO1 \\
\hline 2 & $\begin{array}{l}\text { Education about halal hotels and Hygiene as sharia values in various } \\
\text { marketing channels. interactive content such as Video, Infographic, } \\
\text { and animation will be preferred. }\end{array}$ & $\begin{array}{l}\text { S5; O2; O4; } \\
\quad 06 ; 07\end{array}$ & SO2 \\
\hline 3 & $\begin{array}{l}\text { Lifting the history of the hotel Building which is a cultural heritage, } \\
\text { as its marketing content, namely the Indonesia Heritage Hotel, with } \\
\text { historical value of Indonesian Muslims. }\end{array}$ & $\begin{array}{l}\text { S3; S6; O2; } \\
\text { O6 }\end{array}$ & SO3 \\
\hline 4 & $\begin{array}{l}\text { The sales team creates a member loyalty program for hotel guests } \\
\text { by collecting points as rewards from the hotel }\end{array}$ & $\begin{array}{l}\mathrm{S} 1 ; \mathrm{S} 4 ; \mathrm{T} 3 ; \mathrm{T} 4 \\
\mathrm{~T} 5\end{array}$ & ST1 \\
\hline 5 & $\begin{array}{l}\text { campaign for hygiene protocol to promote Islamic value and health } \\
\text { protocol in the COVID-19 protection. }\end{array}$ & $\begin{array}{l}\text { W1; O4; 072; } \\
\text { T4; T5 }\end{array}$ & W01 \\
\hline 6 & $\begin{array}{l}\text { Introducing the Health Menu to improve immune system, such as } \\
\text { herbal medicine (Jamu), and other healthy menu to promote health } \\
\text { campaign during the COVID-19 pandemic. }\end{array}$ & W2; 05; O7 & WO2 \\
\hline 7 & $\begin{array}{l}\text { Improve information and education on Hotel products regarding } \\
\text { service products and excellence through Instagram and the website. } \\
\text { Digital marketing is a must! }\end{array}$ & $\begin{array}{l}\text { W3; W5; 02; } \\
\text { O5; 06; 07 }\end{array}$ & w03 \\
\hline 8 & $\begin{array}{l}\text { Conducting promotions by providing free food by creating beautiful } \\
\text { photo spots for guests and posting on consumer social media about } \\
\text { their experiences using Hotel services. Collaborative action can be } \\
\text { taken with other restaurant and café providers. }\end{array}$ & $\begin{array}{l}\text { W6; 02; 04; } \\
\quad 05\end{array}$ & WO4 \\
\hline 9 & $\begin{array}{l}\text { SCH Hotel needs to improve the quality of basic products in rooms } \\
\text { by refreshing the rooms appearance by replacing outdated } \\
\text { furniture and redesigning the aesthetic appearance of the rooms. } \\
\text { Most importantly, sanitary products must be provided for each } \\
\text { customer. }\end{array}$ & $\begin{array}{l}\text { W1; T1; T2 } \\
\text { T3; T4; T5 }\end{array}$ & WT1 \\
\hline 10 & $\begin{array}{l}\text { Increase employee responsiveness by providing motivation in the } \\
\text { form of rewards for the best service employees which are } \\
\text { communicated to all responsible employees, including internships }\end{array}$ & W4; T1; T3 & WT2 \\
\hline 11 & $\begin{array}{l}\text { Conducting marketing activities through influencers who provide } \\
\text { reviews of rooms, facilities, and restaurants at SCH Hotel, especially } \\
\text { with the new normal protocol. }\end{array}$ & $\begin{array}{l}\text { W6; W7; T2; } \\
\quad \text { T4; T5 }\end{array}$ & WT3 \\
\hline
\end{tabular}

Source: Author's Analysis

After mapping all the TOWS components, then the authors conducted a TOWS Matrix analysis. The three authors discussed to determine alternative strategies that could be generated from the TOWS components. This discussion process was also carried out with the hotel's director to perform external validity and reliability so that the data validity was guaranteed. To answer the company's strategic objectives, after analyzing and compiling the TOWS matrix analysis result, we suggested several alternative strategies could be applied by $\mathrm{SCH}$ Hotel. the final step, we categorize the TOWS matrix analysis result into several strategic programs. Those programs could be implemented as an alternative to achieve the strategic objective of the hotel vision and mission. Therefore, based on the analysis, we proposed three strategic marketing programs in the new normal after COVID-19 pandemic. We categorized the alternative strategies into the following descriptions: 


\section{Revolution Strategy of SCH - "Hygiene from the heart!"}

The tagline of "Hygiene from the heart" combines Islamic hygiene values with health protocols in avoiding the COVID-19 pandemic. Hotel manager can implement this strategy by creating changes to hotel products to offer services with a fresher and more attractive appearance that aims to attract new consumers or increase the number of consumers. Of course, health protocols must be the priority services and can become the content of marketing programs. The $\mathrm{SCH}$ revolutionary strategy contains the following programs.

1. WT1 (W1; T2 T3; T4; T5) SCH Hotel needs to improve the quality of basic products in the rooms by refreshing the rooms appearance by replacing outdated furniture and redesigning the aesthetic appearance of the rooms. Most importantly, sanitation products must be provided for each customer.

2. WO1 (W1; O4; O72; T4; T5) Campaigning for hygiene protocol to promote Islamic values and health protocols in the COVID-19 protection.

3. WO2 (W2; 05; O7) Introducing the Health Menu to improve immune system, such as traditional food and herbal drink (Jamu), and other healthy menus to promote health campaigns during the COVID-19 pandemic.

\section{Spread the Goodness - Communicating the Optimism of the Tourism Industry}

The "Spread the Goodness" strategy aims to communicate the good values of $\mathrm{SCH}$ and the hotel effort in supporting health protocols in the tourism industry. This strategy is implemented by communicating or providing information about the value of sharia-compliant hotel to consumers, which aims to increase awareness of $\mathrm{SCH}$ Hotel. this strategy contains programs:

1. SO1 (S2; 02; O6) Communicating the new values that have been formed as an identity for Hotel hospitality, especially in the context of occupational Health and Safety standards in avoiding the COVID-19 pandemic.

2. SO2 (S5; 02; 04; O6) Education about halal hotels and the value of Hygiene as sharia values in various marketing channels. The interactive content such as Video, Infographic, and animation will be preferred.

3. SO3 (S6; O2; O6) Lifting the history of the hotel Building which is a cultural heritage, as a marketing content, namely the Indonesia Heritage Hotel, with historical values of Indonesian Muslims.

\section{SCH Powering Strategy - Strengthen the Value of SCH to Muslim Market}

The SCH Powering Strategy aims to strengthen the value of $\mathrm{SCH}$ Hotel for the Muslim market. By strengthening the value of existing products to improve quality for the better, which aims to increase sales from consumers. The strategy consists of:

1. ST1 (S1; S4; T3; T4; T5) The sales team creates a member loyalty program for hotel guests by collecting points for hotel rewards 
2. WT2 (W4; T1; T3) Increase employee responsiveness with motivation in the form of rewards for best service employees communicated to all responsible employees, including internships

3. WT3 (W4; T1; T2; T3) Conducting marketing activities through influencers who provide reviews of rooms, facilities, and restaurants at $\mathrm{SCH}$ Hotel, especially with the new normal protocol.

4. WO3 (W3; W5; 02; 05; 06; 07) Improve information and education of Hotel products regarding service products and excellence through Instagram and the website. Digital marketing is a must!

5. WO4 (W6; 02; 04; 05) Conducting promotions by providing free food and creating beautiful photo spots for guests and posting the pictures on consumer social media about their experiences using Hotel services. Collaborative action can be taken with other restaurant and café providers.

\section{CONCLUSION}

After obtaining the alternative strategies that have been selected through decision analysis, we prioritize the category strategy that must be implemented immediately is the first strategy, namely Revolution Strategy - "Hygiene from The Heart!". This strategy is a global campaign which can be carried out by the shariacompliant hotel in Indonesia regarding the integration of Islamic value on health protocols in avoiding the spread of COVID-19 pandemic. Based on the segmentingtargeting-positioning (STP) context, sharia-compliant hotel must target specific a specific market segment which is Domestic Muslim Travelers who will be the main target of tourists in the upcoming years after the COVID-19 pandemic. Therefore, it is recommended that SCH adjust their STP strategy to suit the new normal era.

Meanwhile, the marketing mix strategy (The 7P's) should be adjusted to the focus of the selected marketing strategy. In the promotion approach, the focus of the strategy is to promote and communicate the Islamic values related to health protocols and hygiene programs. Therefore, management should develop a promotional content which enhance the message that staying with $\mathrm{SCH}$ will comply with hygiene standards and health protocols campaigns during the COVID-19 pandemic. However, based on people and process in marketing mix, this value should be strictly followed by clear standard operating procedure (SOP) by the hotel management.

In accordance with this spirit, hotel management must provide sanitation packages to every customer in addition to hotel amenities and prayer supporting facilities in every hotel room as physical evidence. Meanwhile, in the hotel area, the presence of Islamic hygiene standards such as waste bins and water for ablution should be easily accessible to customers. This SOP will be the basic spirit to campaign the "Hygiene from the heart" in every SCH in Indonesia.

Meanwhile, in hotel restaurant, the presence of halal food is not only the main focus of hotel management. There should be a product development which adds value 
to the menu, not only halal food, but also halal and healthy food which could improve health immune system. Therefore, the idea of serving traditional food such as herbal drink (Jamu) will be beneficial in this strategy.

To see the program's effectiveness in the marketing strategy that has been implemented, an evaluation is carried out every quarter to find out its progress, including monitoring employee performance improvements every month and its impact on service levels which can be seen from guest comment cards. In addition, it is also necessary to monitor whether there are problems that hinder program execution, and immediately provide solutions if there are obstacles. Therefore, good management system should be improved and well monitored.

Although this research applies a single case study approach, the result shows that the alternative strategies could be implemented by any hotels in Indonesia regarding their marketing effort in the new normal era after COVID-19 pandemic. Perhaps in the future research projects in the field of halal tourism and Shariacompliant hotels, researchers could use more hotels in several cities in Indonesia as research objects to enrich the analysis.

\section{Acknowledgement}

Authors would like to appreciate the Indonesia Halal Tourism Association (IHTA/PPHI) for their cooperation in providing the informants, documents, and a comprehensive information during this research. We would also like to thank the reviewers and editors in JEBIS for their meaningful comments.

\section{REFERENCES}

Abodeeb, J., Wilson, E., \& Moyle, B. (2015). Shaping destination image and identity: insights for Arab tourism at the Gold Coast, Australia. International Journal of Culture, Tourism and Hospitality Research, 9(1), 6-21. https://doi.org/10.1108/ijcthr-06-2014-0051

Abror, A., Wardi, Y., Trinanda, O., \& Patrisia, D. (2019). The impact of Halal tourism, customer engagement on satisfaction: moderating effect of religiosity. Asia Pacific Journal of Tourism Research, 24(7), 633-643. https://doi.org/10.1080/10941665.2019.1611609

Al-Ansi, A., \& Han, H. (2019). Role of halal-friendly destination performances, value, satisfaction, and trust in generating destination image and loyalty. Journal of Destination Marketing and Management, 13(May), 51-60. https://doi.org/10.1016/j.jdmm.2019.05.007

Battour, M., \& Ismail, M. N. (2016). Halal tourism: Concepts, practises, challenges and future. Tourism Management Perspectives, 19, 150-154. https://doi.org/10.1016/j.tmp.2015.12.008

Bradford, T. W., \& Boyd, N. W. (2020). Help Me Help You! Employing the Marketing Mix to Alleviate Experiences of Donor Sacrifice. Journal of Marketing, 84(3), 6885. https://doi.org/10.1177/0022242920912272

David, M. E., David, F. R., \& David, F. R. (2017). The quantitative strategic planning matrix: a new marketing tool. Journal of Strategic Marketing. 
https://doi.org/10.1080/0965254X.2016.1148763

de Caro, F., Hirschmann, T. M., \& Verdonk, P. (2020). Returning to orthopaedic business as usual after COVID-19: strategies and options. Knee Surgery, Sports Traumatology, Arthroscopy, 28(1), 1-6. https://doi.org/10.1007/s00167-02006031-3

Fajriyati, I., Afiff, A. Z., Gayatri, G., \& Hati, S. R. H. (2020). Generic and Islamic attributes for non-Muslim majority destinations: application of the three-factor theory of customer satisfaction. Heliyon, 6(6). https://doi.org/10.1016/j.heliyon.2020.e04324

Fauzi, F., Suryanto, T., Anggraeni, E., \& Nasor, M. (2020). the Effect of Tourism Image, Service Quality, and Promotion on Religious Tourism Interest in Pringsewu Regency. Jurnal Ekonomi Dan Bisnis Islam (Journal of Islamic Economics and Business), 6(1), 78. https://doi.org/10.20473/jebis.v6i1.18713

Fernandes, N. (2020). Economic effects of coronavirus outbreak ( COVID-19) on the world economy. SSRN Electronic Journal, ISSN 1556-5068, Elsevier BV,.

Fred, W. (2015). Using the TOWS Matrix Developing Strategic Options From an External-Internal Analysis. MindTools.

Gössling, S., Scott, D., \& Hall, C. M. (2020). Pandemics, tourism and global change: a rapid assessment of COVID-19. Journal of Sustainable Tourism, O(0), 1-20. https://doi.org/10.1080/09669582.2020.1758708

Han, H., Al-Ansi, A., Koseoglu, M. A., Lin, P. M. C., Park, J., Yu, J., \& Kim, W. (2019). Halal tourism: travel motivators and customer retention. Journal of Travel and Tourism Marketing, 36(9), 1012-1024. https://doi.org/10.1080/10548408.2019.1683483

Hasanat, M. W., Hoque, A., Shikha, F. A., Anwar, M., Abdul Hamid, A. B., \& Hon Tat, H. (2020). The Impact of Coronavirus (Covid-19) on E-Business in Malaysia. Asian Journal of Multidisciplinary Studies, 3(1), 1-6.

Hashim, N. I., \& Fauzi, N. M. (2019). The Concept of Shariah Compliant Hotel Business in Malaysia. Online Journal of Research in Islamic ....

Henderson, J. C. (2009). Islamic Tourism Reviewed. Tourism Recreation Research, 34(2), 207-211. https://doi.org/10.1080/02508281.2009.11081594

Huberman, A., \& Miles, M. (2012). Understanding and Validity in Qualitative Research. In The Qualitative Researcher's Companion. https://doi.org/10.4135/9781412986274.n2

Jaelani, A. (2017). Halal Tourism Industry in Indonesia: Potential and Prospects. SSRN Electronic Journal. https://doi.org/10.2139/ssrn.2899864

Jafari, J., \& Scott, N. (2014). Muslim world and its tourisms. Annals of Tourism Research, 44(1), 1-19. https://doi.org/10.1016/j.annals.2013.08.011

Jeaheng, Y., Al-Ansi, A., \& Han, H. (2019). Halal-friendly hotels: impact of halalfriendly attributes on guest purchase behaviors in the Thailand hotel industry. Journal of Travel and Tourism Marketing, 36(6), 729-746. https://doi.org/10.1080/10548408.2019.1631940

Jia, X., \& Chaozhi, Z. (2020). "Halal tourism": is it the same trend in non-Islamic destinations with Islamic destinations? Asia Pacific Journal of Tourism Research, 25(2), 189-204. https://doi.org/10.1080/10941665.2019.1687535

Kotler, P. (2011). Reinventing marketing to manage the environmental imperative. In Journal of Marketing. https://doi.org/10.1509/jmkg.75.4.132 
Lovelock, C., \& Gummesson, E. (2004). Whither Services Marketing?: In Search of a New Paradigm and Fresh Perspectives. Journal of Service Research. https://doi.org/10.1177/1094670504266131

Maulana, N. (2017). The influence of barosok trading system on ethical business behavior in the husbandry sector in West Sumatera. Journal of Advanced Research in Social Sciences and Humanities, 2(2), 131-138. https://doi.org/10.26500/jarssh-02-2017-0208

Maulana, N. (2020a). Menelisik Strategi Pemasaran Rumah Sakit Menggunakan Market Based-Management. Jurnal Manajemen Bisnis, 17(3), 374-395. https://doi.org/http://dx.doi.org/10.38043/jmb.v17i3.2527

Maulana, N. (2020b). Research Trends in Marketing Science before COVID-19 Outbreak: A Literature Review. Management and Marketing, 15(s1), 514-533. https://doi.org/10.2478/mmcks-2020-0030

Maxwell, J. A. (2002). Understanding and Validity in Qualitative Research. In A. M. Huberman \& M. B. Miles (Eds.), The Qualitative Researcher's Companion. https://doi.org/10.4135/9781412986274.n2

Mohammad, M. T., Hannan, A., \& Maadi, A. S. (2019). the Marketing Strategy of Madura Tourism Industry Area Trough Sustainable Development Based Gender. Jurnal Ekonomi Dan Bisnis Islam (Journal of Islamic Economics and Business), 5(1), 82. https://doi.org/10.20473/jebis.v5i1.13987

Mohsin, A., Ramli, N., \& Alkhulayfi, B. A. (2016). Halal tourism: Emerging opportunities. Tourism Management Perspectives, 19(2016), 137-143. https://doi.org/10.1016/j.tmp.2015.12.010

Palupi, M., Romadhon, R. W., \& Arifan, N. (2017). The importance of optimization of Halal tourism: A study of the development of Halal tourism in Indonesia. Proceedings of the 29th International Business Information Management Association Conference - Education Excellence and Innovation Management through Vision 2020: From Regional Development Sustainability to Global Economic Growth, September, 3083-3092.

Ptok, A., Jindal, R. P., \& Reinartz, W. J. (2018). Selling, general, and administrative expense (SGA)-based metrics in marketing: conceptual and measurement challenges. Journal of the Academy of Marketing Science, 46(6), 987-1011. https://doi.org/10.1007/s11747-018-0589-2

Ratnasari, R. T., Gunawan, S., Mawardi, I., \& Kirana, K. C. (2020). Emotional experience on behavioral intention for halal tourism. Journal of Islamic Marketing. https://doi.org/10.1108/JIMA-12-2019-0256

Ravanavar, G. M. (2012). Strategic Formulation Using Tows Matrix - A Case Study. International Journal of Research and Development.

Rodrigo, P., \& Turnbull, S. (2019). Halal holidays: How is value perceived by Muslim tourists? International Journal of Tourism Research, 21(5), 675-692. https://doi.org/10.1002/jtr.2290

Saputro, M. S. D., Wardi, Y., \& Abror, A. (2018). The Effect of Halal Tourism on Customer Satisfaction. 57(Piceeba), 275-282. https://doi.org/10.2991/piceeba18.2018.57

Sekaran, U., \& Bougie, R. (2011). Business Research Methods: A skill-building approach. In Wiley.

https://doi.org/http://as.wiley.com/WileyCDA/WileyTitle/productCd- 
Maulana, Oktaviaman, Farah,

111994225X.html\#

Snyder, H. (2019). Literature review as a research methodology: An overview and guidelines. Journal of Business Research, 104(March), 333-339.

https://doi.org/10.1016/j.jbusres.2019.07.039

Suwanto, S. (2020). Hubungan Jumlah Kunjungan Wisatawan Mancanegara dengan Rata-Rata Tingkat Penghunian Kamar Hotel Provinsi DKI Jakarta Tahun 20122018. Jurnal Kepariwisataan Indonesia : Jurnal Penelitian Dan Pengembangan Kepariwisataan Indonesia, 14(1), 9-20. https://doi.org/10.47608/jki.v14i12020.9-20

Usman, H., Java, W., \& Sari, L. E. (2019). Sharia motivation in Muslim tourism de fi nition, does it matter? 10(3), 709-723. https://doi.org/10.1108/JIMA-01-20180015

USMAN, H., SOBARI, N., \& HASAN, F. A. AL. (2020). The Impact of Sharia Compliance on Sharia Hotel Services and Customers Satisfaction. Journal of Business Economics and Environmental Studies. https://doi.org/10.13106/jbees.2020.vol10.no3.5

Weihrich, H. (1982). The TOWS matrix-A tool for situational analysis. Long Range Planning. https://doi.org/10.1016/0024-6301(82)90120-0

Winarti, O. (2017). Halal Tourism in Indonesia: Does it attract only Muslim Tourists? Jurnal Studi Komunikasi (Indonesian Journal of Communications Studies). https://doi.org/10.25139/jsk.v1i3.139 